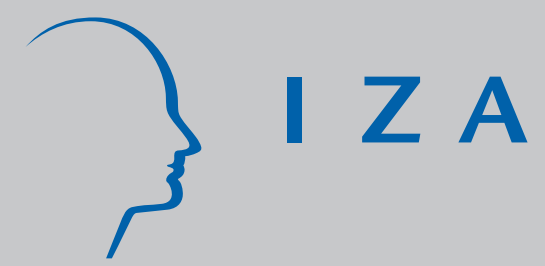

IZA DP No. 7019

English Deficiency and the Native-Immigrant Wage Gap

Alfonso Miranda

Yu Zhu

November 2012

Forschungsinstitut

zur Zukunft der Arbeit

Institute for the Study

of Labor 


\title{
English Deficiency and the Native-Immigrant Wage Gap
}

\author{
Alfonso Miranda \\ CIDE and IZA
}

Yu Zhu

University of Kent

\section{Discussion Paper No. 7019 \\ November 2012}

\author{
IZA \\ P.O. Box 7240 \\ 53072 Bonn \\ Germany \\ Phone: +49-228-3894-0 \\ Fax: +49-228-3894-180 \\ E-mail: iza@iza.org
}

Any opinions expressed here are those of the author(s) and not those of IZA. Research published in this series may include views on policy, but the institute itself takes no institutional policy positions. The IZA research network is committed to the IZA Guiding Principles of Research Integrity.

The Institute for the Study of Labor (IZA) in Bonn is a local and virtual international research center and a place of communication between science, politics and business. IZA is an independent nonprofit organization supported by Deutsche Post Foundation. The center is associated with the University of Bonn and offers a stimulating research environment through its international network, workshops and conferences, data service, project support, research visits and doctoral program. IZA engages in (i) original and internationally competitive research in all fields of labor economics, (ii) development of policy concepts, and (iii) dissemination of research results and concepts to the interested public.

IZA Discussion Papers often represent preliminary work and are circulated to encourage discussion. Citation of such a paper should account for its provisional character. A revised version may be available directly from the author. 
IZA Discussion Paper No. 7019

November 2012

\section{ABSTRACT}

\section{English Deficiency and the Native-Immigrant Wage Gap*}

We focus on the effect of English deficiency on the native-immigrant wage gap for male employees in the UK using the first wave of the UK Household Longitudinal Survey. We show that the wage gap is robust to controls for age, region of residence, educational attainment and ethnicity. However, English as Additional Language (EAL) is capable of explaining virtually all the remaining wage gap between natives and immigrants. Using the interaction of language of country of birth and age-at-arrival as instrument, we find strong evidence of a causal effect of EAL on the native-immigrant wage gap.

JEL Classification: J15, J61

Keywords: native-immigrant wage gap, English as Additional Language (EAL), age-at-arrival

Corresponding author:

Yu Zhu

School of Economics

University of Kent

Canterbury, CT2 7NP

United Kingdom

E-mail: yz5@kent.ac.uk 


\section{Introduction}

This paper investigates to what extent English deficiency explains the native-immigrant wage gap for males in the UK, after controlling for age, region of residence, educational attainment and ethnicity. Previous work have found that, upon immigration, good command of the language of the destination county carries a positive return of around 15$25 \%$ for migrants in the labour market (see e.g. Chiswick 1991, Chiswick and Miller 1999, Dustmann 1994). In the UK Dustmann and Fabbri (2003) report a return of about $18-20 \%$ using the Family and Working Lives Survey (FWLS) as well as the Fourth National Survey on Ethnic Minorities (FNSEM). However, after controlling for the potential endogeneity of English proficiency they find no statistically significant effect. This may be due to the small sample size the wage equations were fitted on, with 250 observations for the FWLS and 920 observations for the FNSEM.

Our contribution to the literature is threefold. The Dustmann and Fabbri (2003) study analysed data collected in the first half of the 1990s. Since that time, the UK has received a significant inflow of new migrants from Eastern Europe, following the expansion of the European Union. Hence, it is interesting to revisit the topic and investigate whether the returns to English proficiency remain at the same level as those reported nearly 20 years ago. Second, our analyses are based on a larger sample of immigrants, enabling us to estimate tighter confidence intervals. Finally, we use an IV strategy to address the issue of potential endogeneity of our English language proficiency indicator. Endogeneity may arise from two different sources: (i) self-selection into treatment, and (ii) measurement error. We address the 'aggregate' endogeneity problem using an IV strategy, without making an attempt to disentangle the contribution of the two sources of bias. Following Bleakley and Chin $(2004,2010)$ and van Ours and Veenman (2006), we use language of the origin country as well as its interaction with age-at-arrival as instrumental variables for the subpopulation of immigrants. Our identification strategy effectively compares older and younger arrivers from non-English-speaking countries, after controlling for an age-at-arrival effect which is common for all immigrants regardless of their native language. This identification strategy delivers a Local Average Treatment Effect (LATE) that is straightforward to interpret for the subpopulation of immigrants affected by the 
instrument. Hence, this is an improvement to alternative identification strategies that have been used in the past.

\section{Data and set-up of the analysis}

Our empirical analysis is based on the first wave of the UK Household Longitudinal Survey, a longitudinal survey of just over 30,000 households in the UK in 2009-2011, including around 4,000 from the ethnic minority boost sample. We focus on the nativeimmigrant wage gap of male employees aged 19-60. Natives are defined as UK-born whites who speak English as first language. Conversely, immigrants are defined as people who were born abroad to two non-native parents. ${ }^{1}$ After excluding missing values and outliers of log real hourly wage ${ }^{2}$, we end up with a sample of 6,959 males, of which 1,203 are immigrants.

Table 1 reports summary statistics by immigrant status. The raw native-immigrant wage gap is a highly statistically significant $0.159 \mathrm{log}$ points in favour of natives. However, this does not take into account any composition effect. Indeed, these two samples have very different characteristics. For instance, male immigrants in the UK are on average younger, hold higher qualifications, and live disproportionately in London compared to white natives. $71 \%$ of the immigrants declare speaking English as Additional Language (EAL), while $87 \%$ of them were born in developing countries. A significant minority (18.5\%) of male immigrants are white, of which $71 \%$ were born in European countries. ${ }^{3}$

\section{$3 \quad$ Results and discussions}

In a wage equation, we measure the immigrant wage effect by a dummy variable, with a negative coefficient indicating a regression-adjusted native-immigrant wage gap in favour of natives. In Table 2 we successively introduce control variables. The nativeimmigrant wage gap increases by $0.10 \log$ points when differences in age profiles and region of residence are accounted for in column 1. Moreover, once highest qualifications are controlled for in column 2 the gap widens by another $0.02 \log$ points. When ethnicity

1 Blackaby et al. (2005) have studied the employment and earnings differentials between whites and UKborn ethnic minorities using a decomposition approach. We only include non UK-born immigrants in the treatment group, in order to exploit the variation in English deficiency induced by the variation in the ageat-arrival of immigrants from non-English-speaking versus English-speaking countries.

2 We exclude the top and bottom $1 \%$ of wages by highest qualification and ethnicity.

$327 \%$ of immigrants arriving in the UK since 2004 are white, of which $61 \%$ are from Poland. 
dummies are added in column 3, the gap is reduced to $0.117 \log$ points, only one-quarter smaller than the raw differential. This implies that even white immigrants (the reference ethnicity category) suffer from large wage penalties compared to natives, holding age, region and education constant.

We then explore to what extent English deficiency explains this remaining wage gap in the next two columns. When EAL is added in column 4, the gap is reduced to $0.018 \log$ points in favour of immigrants and becomes statistically insignificant. This implies that the entire remaining wage gap is explained by English deficiency. When we further include a dummy for immigrating from a developing country ${ }^{4}$ and dummies for age-atarrival in the UK for immigrants (column 5), the immigrant coefficient even turns into a positive and statistically significant $0.132 \mathrm{log}$ points while the EAL effect remains significant and is of the same magnitude as the raw wage gap. ${ }^{5}$ The fact that all age-atarrival dummies are strongly negative suggests that for white immigrants arriving in the UK before 10 (the omitted category), there is no disadvantage associated with being an immigrant, holding all else constant.

In Table 3 we address the potential endogeneity of EAL using both the full sample and the subsample of immigrants only. In column 1, we instrument EAL using born in a nonEnglish-speaking country as well as its interaction with a dummy for age-at-arrival greater than 9. Figure A1 shows the regression-adjusted mean probability of EAL, with $95 \%$ confidence intervals, by age-at-arrival and home country language. Immigrants from non-English-speaking countries who arrived before the age of 10-14 are, statistically, as likely to be EAL as immigrants from English-speaking countries. In contrast, if immigration occurred after age 10-14 the two groups are statistically different. Following the theory of the critical period for second language acquisition Bleakley and Chin (2004, 2010) argue that, after controlling for educational attainment and other background variables, differences in English proficiency between immigrants from English-speaking and non-English-speaking countries before and after age 10 are uncorrelated with current wages because any non-language age-at-arrival wage effects are the same for all

4 The developing country dummy might partly capture the differences in quality of education.

5 We include age, age square and age-at-arrival in bands of 0-9, 10-15, 16-29 and 30+ to disentangle the effect of assimilation and effects of language. However, our identification only relies on the interaction between born in a non-English speaking country and age-at-arrival greater than 9 . 
immigrants regardless of their home country language. Notice that under the postulated identification strategy the IV estimator is analogous to a difference-in-differences estimator that calculates language wage effects net of age-at-arrival wage effects.

The bottom panel of Table 3 shows that the instruments are strong predictors of EAL status both individually and jointly. Being born in a non-English-speaking country increases the incidence of EAL by 33\% while arriving in the UK after age 9 from a nonEnglish-speaking country increases the probability by another $49 \%$. Moreover, the model also easily passes the over-identification test. We find that EAL effect becomes larger when we allow it to be endogenous but remains statistically significant at the $5 \%$ level, although we won't be able to reject the null of equality with the OLS estimate. On the other hand, the immigrant wage effect remains virtually the same as in the OLS specification.

Column 2 shows that instrumenting using the interaction term only makes no difference. The just-identified IV is unlikely to be subject to a weak-instrument critique. GMM and LIML estimates (available upon request) also come out very similar, lending further support to the robustness of our IV results.

Columns 3 and 4 replicate the 2SLS estimation, using the subsample of immigrants only. The fact that two sets of results are virtually identical implies that the causal effect of EAL is identified by variation within the sub-population of immigrants in English deficiency induced by age-at-arrival between immigrants from English-speaking and non-English-speaking countries.

\section{Conclusions}

We find a composition-adjusted male native-immigrant wage gap in the UK of $12 \%$, slightly below the raw wage differential. However, this gap virtually disappears after controlling for the EAL indicator. We address the endogeneity of EAL with an IV strategy and use born in non-English-speaking country and age-at-arrival as instruments for identifying a LATE that is straightforward to interpret for the subpopulation of firstgeneration immigrants affected by the instrument. Our IV regressions indicate that EAL 
has a causal negative effect of $-23 \%$ on wages, which is significant at $5 \%$, and robust to various specifications.

\section{References}

Blackaby, D.H., Leslie, D.G., Murphy, P.D., O’Leary, N.C., 2005. Born in Britain: How are Native Ethnic Minorities Faring in the British Labour Market? Economics Letters 88, $370-375$.

Bleakley, H., Chin, A., 2004. Language skills and earnings: evidence from childhood immigrants. Review of Economics and Statistics 86, $481-496$.

Bleakley, H., Chin, A., 2010. Age-at-arrival, English proficiency, and social assimilation among US immigrants. American Economic Journal: Applied Economics 2, 165-192.

Chiswick, B.R., 1991. Speaking, reading, and earnings among low-skilled immigrants. Journal of Labor Economics 9, 149-70.

Chiswick, B.R., Miller, P.W., 1999. Language skills and earnings among legalised aliens. Journal of Population Economics 12, 63-89.

Dustmann, C., 1994. Speaking fluency, writing Fluency and earnings of migrants. Journal of Population Economics 7, 133-56.

Dustmann, C., Fabbri, F. 2003. Language proficiency and labour market performance in the UK. Economic Journal 113, 695-717.

Van Ours, J. C., Veenman, J., 2006. Age at immigration and educational attainment of young immigrants. Economics Letters 90, 310-316. 
Table 1: Summary statistics, by immigrant status

\begin{tabular}{|c|c|c|c|}
\hline & Natives $(\mathrm{N}=5756)$ & Immigrants $(\mathrm{N}=1203)$ & Native-immigrant gap \\
\hline Log real hourly wage & 2.504 & 2.345 & $0.159 * *$ \\
\hline EAL & 0 & 0.710 & $-0.710 * *$ \\
\hline Born in developing country & 0 & 0.874 & $-0.874 * *$ \\
\hline No qualification & 0.141 & 0.162 & $-0.022 *$ \\
\hline Below GCSE/O-Level & 0.094 & 0.076 & $0.017 * *$ \\
\hline GCSE/O-Level & 0.286 & 0.081 & $0.206 * *$ \\
\hline A-Level & 0.119 & 0.097 & $0.022 * *$ \\
\hline Higher Education Diploma & 0.089 & 0.086 & 0.004 \\
\hline First Degree & 0.173 & 0.212 & $-0.039 * *$ \\
\hline Higher Degree & 0.097 & 0.285 & $-0.187 * *$ \\
\hline Highest qualification is foreign & 0.002 & 0.392 & $-0.389 * *$ \\
\hline Age & 40.3 & 37.5 & $2.8 * *$ \\
\hline White & 1.000 & 0.185 & $0.815 * *$ \\
\hline Mixed & 0 & 0.013 & $-0.013 * *$ \\
\hline Asian & 0 & 0.552 & $-0.552 * *$ \\
\hline Black & 0 & 0.140 & $-0.140 * *$ \\
\hline Other Ethnicity & 0 & 0.111 & $-0.111 * *$ \\
\hline London & 0.061 & 0.485 & $-0.424 * *$ \\
\hline Southeast & 0.132 & 0.069 & $0.063 * *$ \\
\hline Rest of England & 0.615 & 0.391 & $0.223 * *$ \\
\hline Wales & 0.051 & 0.009 & $0.042 * *$ \\
\hline Scotland & 0.098 & 0.030 & $0.068 * *$ \\
\hline Northern Ireland & 0.044 & 0.016 & $0.028 * *$ \\
\hline
\end{tabular}

Note: $* *(*)=$ significant at $5 \%(10 \%)$ level based on Welch's t-test.

Table 2: OLS wage equations, pooled natives and immigrants sample $(\mathrm{N}=6959)$

\begin{tabular}{|c|c|c|c|c|c|}
\hline & (1) & (2) & (3) & (4) & (5) \\
\hline Immigrant & $-0.258(13.7)^{* *}$ & $-0.276(14.0)^{* *}$ & $-0.117(3.2)^{* *}$ & $0.018(0.4)$ & $0.132(2.3)^{* *}$ \\
\hline EAL & & & & $-0.198(6.0)^{* *}$ & $-0.158(4.4)^{* *}$ \\
\hline Born in developing country & & & & & $-0.092(1.8)^{*}$ \\
\hline Age-at-arrival $10-15$ & & & & & $-0.136(2.2)^{* *}$ \\
\hline Age-at-arrival 16-29 & & & & & $-0.090(2.0)^{* *}$ \\
\hline Age-at-arrival $30+$ & & & & & $-0.172(3.2)^{* *}$ \\
\hline Highest qualification dummies & no & Yes & yes & yes & yes \\
\hline Ethnicity dummies & no & No & yes & yes & yes \\
\hline
\end{tabular}

Note: Absolute t-statistics based on robust standard errors in parentheses; $* *(*)=$ significant at $5 \%(10 \%)$ level. Other controls include age, age squared and region dummies.

Table 3: 2SLS wage equations

\begin{tabular}{|c|c|c|c|c|}
\hline & \multicolumn{2}{|c|}{ Full sample } & \multicolumn{2}{|c|}{ Immigrants only } \\
\hline & $\begin{array}{l}\text { IV (over- } \\
\text { identified) }\end{array}$ & IV (just-identified) & $\begin{array}{l}\text { IV (over- } \\
\text { identified) }\end{array}$ & IV (just-identified) \\
\hline Immigrant & $0.151(2.5)^{* *}$ & $0.151(2.5)^{* *}$ & & \\
\hline EAL & $-0.253(2.4)^{* *}$ & $-0.251(2.3)^{* *}$ & $-0.232(2.2)^{* *}$ & $-0.242(2.3)^{* *}$ \\
\hline Born in developing country & $-0.061(1.0)$ & $-0.062(1.0)$ & $-0.085(1.4)$ & $-0.081(1.3)$ \\
\hline Age-at-arrival $10-15$ & $-0.110(1.6)$ & $-0.111(1.6)$ & $-0.145(2.1)^{* *}$ & $-0.142(2.0)^{* *}$ \\
\hline Age-at-arrival 16-29 & $-0.056(1.0)$ & $-0.057(1.0)$ & $-0.076(1.3)$ & $-0.072(1.3)$ \\
\hline Age-at-arrival $30+$ & $-0.135(2.0)^{* *}$ & $-0.136(2.1)^{* *}$ & $-0.125(1.8)^{*}$ & $-0.121(1.8)^{*}$ \\
\hline $\mathrm{p}$-value for over-identification test & 0.887 & - & 0.612 & - \\
\hline First stage $($ dependent variable $=$ EAL $)$ & & & & \\
\hline Born in non-English-speaking country & $0.330(2.7)^{* *}$ & & $0.332(2.8)^{* *}$ & \\
\hline $\begin{array}{l}\text { Born in non-English-speaking country } \\
*(\text { age-at-arrival }>9)\end{array}$ & $0.487(4.1)^{* *}$ & $0.764(19.0)^{* *}$ & $0.490(4.3)^{* *}$ & $0.767(18.8)^{* *}$ \\
\hline F-stat for exclusion restrictions ( $\mathrm{p}$-value) & $248.9(0.000)$ & $359.7(0.000)$ & $228.0(0.000)$ & $353.9(0.000)$ \\
\hline
\end{tabular}




\section{APPENDIX}

Figure A1: Fitted EAL probability by age-at-arrival and home country language

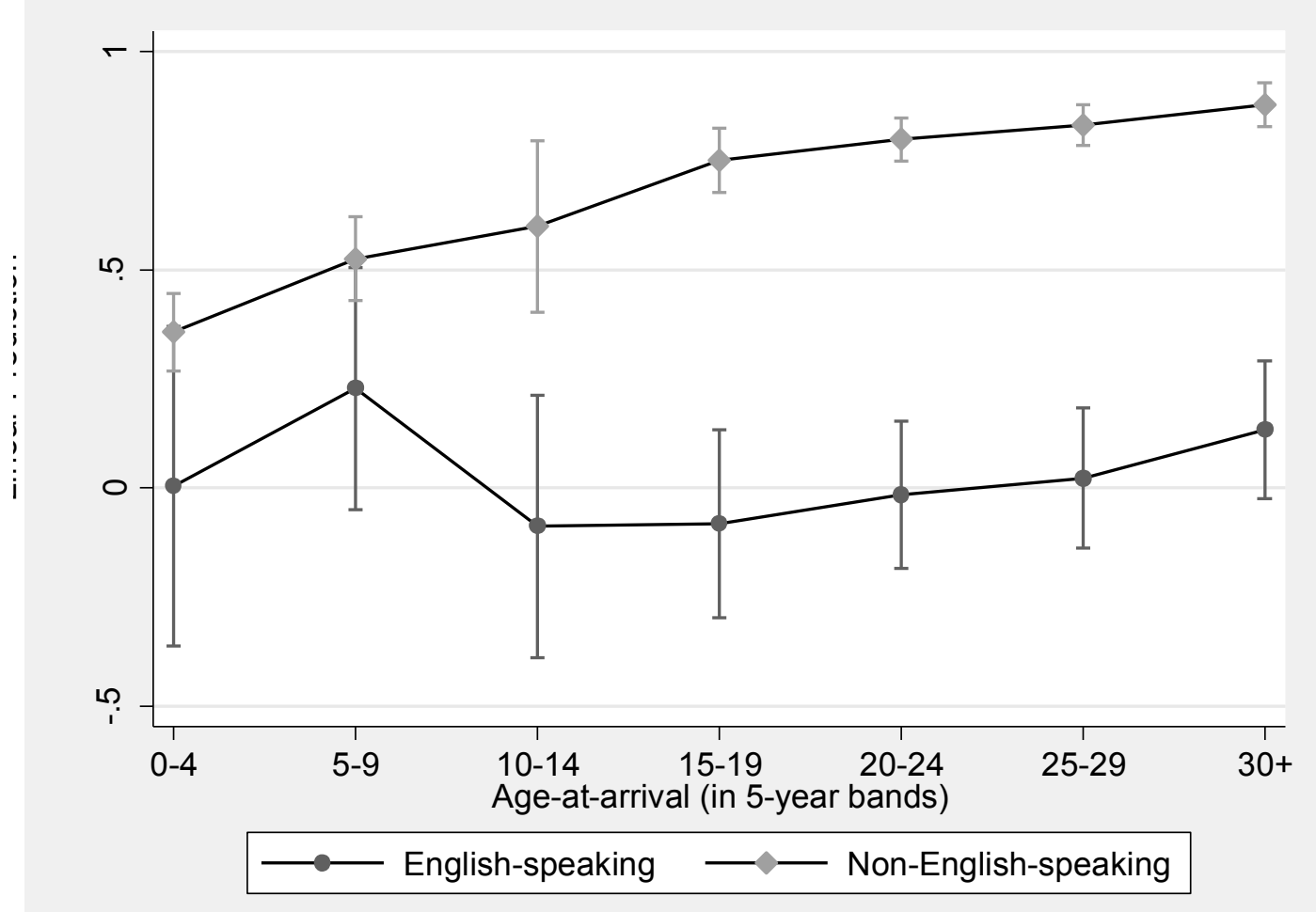

